\title{
Individual differences in body temperature and the relation to energy expenditure: the influence of mild cold
}

Citation for published version (APA):

van Ooijen, A. M. J., van Marken Lichtenbelt, W. D., \& Westerterp, K. R. (2001). Individual differences in body temperature and the relation to energy expenditure: the influence of mild cold. Journal of Thermal Biology, 26, 455-459. https://doi.org/10.1016/S0306-4565(01)00060-2

Document status and date:

Published: 01/01/2001

DOI:

10.1016/S0306-4565(01)00060-2

Document Version:

Publisher's PDF, also known as Version of record

Document license:

Taverne

Please check the document version of this publication:

- A submitted manuscript is the version of the article upon submission and before peer-review. There can be important differences between the submitted version and the official published version of record.

People interested in the research are advised to contact the author for the final version of the publication, or visit the DOI to the publisher's website.

- The final author version and the galley proof are versions of the publication after peer review.

- The final published version features the final layout of the paper including the volume, issue and page numbers.

Link to publication

\footnotetext{
General rights rights.

- You may freely distribute the URL identifying the publication in the public portal. please follow below link for the End User Agreement:

www.umlib.nl/taverne-license

Take down policy

If you believe that this document breaches copyright please contact us at:

repository@maastrichtuniversity.nl

providing details and we will investigate your claim.
}

Copyright and moral rights for the publications made accessible in the public portal are retained by the authors and/or other copyright owners and it is a condition of accessing publications that users recognise and abide by the legal requirements associated with these

- Users may download and print one copy of any publication from the public portal for the purpose of private study or research.

- You may not further distribute the material or use it for any profit-making activity or commercial gain

If the publication is distributed under the terms of Article 25fa of the Dutch Copyright Act, indicated by the "Taverne" license above, 


\title{
Individual differences in body temperature and the relation to energy expenditure: the influence of mild cold
}

\author{
A.M.J. van Ooijen*, W.D. van Marken Lichtenbelt, K.R. Westerterp \\ Department of Human Biology, Maastricht University, P.O. Box 616, Universiteitssingel 50, 6200 Maastricht, The Netherlands
}

\begin{abstract}
Inter-individual differences in body temperature and resting metabolic rate (RMR), during comfortable temperature and mild cold were studied. Sleeping metabolic rate (SMR) was measured overnight at $22^{\circ} \mathrm{C}$ and RMR the following morning at $22^{\circ} \mathrm{C}$ and at $16^{\circ} \mathrm{C}$. Intestinal, rectal and skin temperatures were measured as well as the electromyography (EMG). The SMR and the RMR corrected for body composition were significantly related $\left(p<0.001, r^{2}=0.57\right)$ which means that individual levels of energy expenditure during the night remained during the day. At $16^{\circ} \mathrm{C}$, the RMR increased without increase of EMG activity, indicating non-shivering thermogenesis. Gender differences exist for intestinal, rectal, pectoralis and hand temperature $(p<0.05)$. (C) 2001 Elsevier Science Ltd. All rights reserved.
\end{abstract}

Keywords: Body temperature; Core temperature; Skin temperature; Temperature gradient; Energy expenditure; SMR; RMR; Cold; Gender differences; Heat loss

\section{Introduction}

Inter-individual differences in resting metabolic rate (RMR) can, to a large extent be explained by body composition (fat free mass (FFM) and fat mass (FM)). However, the RMR adjusted for these covariates is still subject to significant inter-individual variation (Bogardus et al., 1986; Ravussin and Bogardus, 1989). These differences in metabolic rate may be genetically determined and can have important health implications. People with low metabolic rates have a higher risk of weight gain.

Studies in animals and humans have shown that the differences in metabolic rate are related to differences in body temperature. In a study on the relation between aerobic power and RMR in women, oral body temperature correlated with RMR $(\mathrm{kJ} \mathrm{kg}$ fat free mass $^{-1} \mathrm{~h}^{-1}$ ) (Smith et al., 1997). Another study showed that in Pima Indians, the metabolic rate adjusted for

*Corresponding author. Tel.: + 31-43-3882111; fax: + 31-433670976.

E-mail address: m.vanooijen@hb.unimaas.nl (A.M.J. van Ooijen). body composition was related to body temperature (Rising et al., 1992).

Twenty-four hour energy expenditure was found to be higher at mild cold compared to a comfortable environmental temperature. However, there is a controversy in results on the separate components of $24 \mathrm{~h}$ energy expenditure (e.g. RMR, dietary induced thermogenesis, activity induced energy expenditure) (Dauncey, 1981; Valencia et al., 1992). Additionally, we found that the average daily metabolic rate (ADMR) corrected for body composition, correlates with core temperature and that metabolic rate responds to changes in ambient temperature (van Marken Lichtenbelt et al., 2000). Moreover, experiments on short-term exposure to cold (i.e. several hours or less) describe an increase in energy expenditure, the discussion in this case is whether or not non-shivering thermogenesis contributes to the process (Paolone and Paolone, 1995; Huttunen et al., 2000; Vybiral et al., 2000).

The aim of this study was to determine the magnitude of inter-individual and gender differences in body temperature (BT) and RMR, during comfortable temperature and mild cold. The second goal was to study the relation between BT and RMR and the change 
of BT and RMR in response to a decrease in ambient temperature.

\section{Materials and methods}

\subsection{Design}

Subjects visited the university building for an overnight stay and the following morning to conduct the experiment. Body composition was determined on a separate visit within one week of the experiment. During the overnight stay at $22^{\circ} \mathrm{C}$, sleeping metabolic rate (SMR) and intestinal temperature were measured. During sleep, subjects were covered with a duvet $\left(375 \mathrm{~g} / \mathrm{m}^{2}\right)$. In the morning, RMR, intestinal, rectal and skin temperatures were measured for $1 \mathrm{~h}$ at $22^{\circ} \mathrm{C}$ followed by three hours at $16^{\circ} \mathrm{C}$. The data were averaged over the second half hour at $22^{\circ} \mathrm{C}$ and over the second and the last half hour at $16^{\circ} \mathrm{C}$. Subjects were lying supine on a stretcher. Clothing had an isolative value of $0.71 \mathrm{clo}$ $\left(I_{\mathrm{cl}}=0.109 \mathrm{~m}^{2}{ }^{\circ} \mathrm{C} / \mathrm{W}\right)$ and consisted of sweatpants $(0.28 \mathrm{clo})$, a sweater $(0.37 \mathrm{clo})$, socks $(0.02 \mathrm{clo})$ and panties and bra for women and briefs for men $(0.04 \mathrm{clo})$. The face, hands and ankles were exposed directly to the mild cold.

\subsection{Subjects}

Subjects were 13 women and 12 men age, 19-36 years, BMI $17-30 \mathrm{~kg} / \mathrm{m}^{2}$, non-smoking and non-medicated (Table 1).

Detailed information concerning purpose and methods used in the study was provided before written consent was obtained. The Ethics Committee of Maastricht University approved the study.

\subsection{Measurements}

Body composition was determined using underwaterweighing and calculated according to Siri (1956). During the night $\mathrm{O}_{2}$ consumption and $\mathrm{CO}_{2}$ production were

Table 1

Subject characteristics

\begin{tabular}{cccc}
\hline & $\begin{array}{l}\text { Mean } \\
n=25\end{array}$ & $\begin{array}{l}\text { Males } \\
n=12\end{array}$ & $\begin{array}{l}\text { Females } \\
n=13\end{array}$ \\
\hline Age $(\mathrm{yr})$ & $26 \pm 5$ & $27 \pm 6$ & $25 \pm 3$ \\
Height $^{\mathrm{a}}(\mathrm{m})$ & $1.75 \pm 0.09$ & $1.83 \pm 0.04$ & $1.67 \pm 0.06$ \\
Weight $^{\mathrm{a}}(\mathrm{kg})$ & $70.4 \pm 14.4$ & $79.4 \pm 14.4$ & $62.2 \pm 8.4$ \\
${\text { BMI }\left(\mathrm{kg} / \mathrm{m}^{2}\right)}^{2}$ & $22.9 \pm 3.3$ & $23.8 \pm 3.9$ & $22.2 \pm 2.6$ \\
$\mathrm{FM}^{\mathrm{a}}(\%)$ & $22 \pm 9$ & $16 \pm 8$ & $27 \pm 7$ \\
\hline
\end{tabular}

${ }^{\mathrm{a}} p<0.01$ between males and females. measured in a $14 \mathrm{~m}^{3}$ respiration chamber as previously described (Schoffelen et al., 1997). During the morning tests, $\mathrm{O}_{2}$ consumption and $\mathrm{CO}_{2}$ production were measured with an automated respiratory gas analyser using a ventilated hood system (Omnical, Maastricht University, The Netherlands). Gas analysers were calibrated previous to the experiments. Energy expenditure was calculated from these data according to Weir (1990).

The SMR was defined as the average metabolic rate during at least $3 \mathrm{~h}$ of sleep with the lowest activity according to radar. The RMR was defined as the metabolic rate, lying still and awake.

Intestinal temperature was measured by an ingestible telemetry pill (CorTemp, Human Technologies, Inc., St Petersburg, FL) which was ingested before entering the respiration chamber (O'Brien et al., 1998). Rectal temperature was measured by a thermistor-probe (YSI probes, series 402, Yellow Springs Instruments Co. Ltd., $\mathrm{OH}$, USA) inserted to a depth of $10 \mathrm{~cm}$. Skin temperatures were measured by suface-thermistors (YSI probes, series 409B, Yellow Springs Instruments Co. Ltd., OH, USA) placed at the back of the hand, upperarm, m. pectoralis, abdomen located at the liver, at the back located at the liver, thigh, calf, foot and one sensor placed above the clothing located at the liver. Temperatures were measured at 1-min intervals. Skin temperature was calculated according to Ramanathan (1964). Proximal temperature was calculated, averaging temperatures measured at the upper arm, chest located at the m.pectoralis major, abdomen located at the liver, back located at the liver and thigh. Distal temperature was calculated, averaging temperatures measured at the hand and foot. Temperature gradients were calculated between core and skin, skin and ambient temperature and between proximal and distal skin temperature. The possible onset of shivering was detected using electromyography (EMG) (K-lab, Amsterdam, The Netherlands) at the $\mathrm{m}$. pectoralis major (Bell et al., 1992; Tikuisis et al., 1991).

\subsection{Analyses}

Data are reported as means $\pm \mathrm{SD}$. For intra-individual differences in body temperatures between the two ambient temperatures and for inter-individual differences between genders, respectively paired and unpaired $t$-tests were used. Regression analysis was used to study the relation between energy expenditure and body temperature. Residuals of SMR and RMR were calculated as the difference between the measured and predicted values of energy expenditure. Calculation of predicted values of SMR and RMR was based on multiple regression analysis including FFM and FM. Analysis of covariance (ANCOVA) was used to 
compare energy expenditure corrected for FFM. Level of significance was set at $\alpha=0.05$.

\section{Results}

\subsection{Energy expenditure}

Absolute values of both SMR and RMR could be explained by FFM for more than $85 \%$ (SMR $r^{2}=0.86$, $\left.\mathrm{RMR} r^{2}=0.85\right)$. Including FM or gender did not result in a significant increase of explained variation, nevertheless, for comparability with other studies, FM was included in multiple linear regression analyses for calculations of residuals. Women had a lower SMR, RMR and FFM than men. After adjustment for body composition, no significant gender differences in SMR and RMR were found. Residuals of SMR were related to residuals in $\mathrm{RMR}\left(p<0.001, r^{2}=0.57\right)$ (Fig. 1). This means that individual levels of energy expenditure during the night remained during the day.

In the first hour at $16^{\circ} \mathrm{C}, \mathrm{RMR}$ increased on average by $5 \%$ compared to $22^{\circ} \mathrm{C}(p<0.05)$ (Fig. 2$)$. Although the difference was smaller than during the first hour at $16^{\circ} \mathrm{C}$, during the last hour at $16^{\circ} \mathrm{C}$, the RMR remained significantly elevated compared to $22^{\circ} \mathrm{C}$. During the $16^{\circ} \mathrm{C}$ test, no possible onset of shivering was registered by EMG and the subjects reported no sensation of shivering.

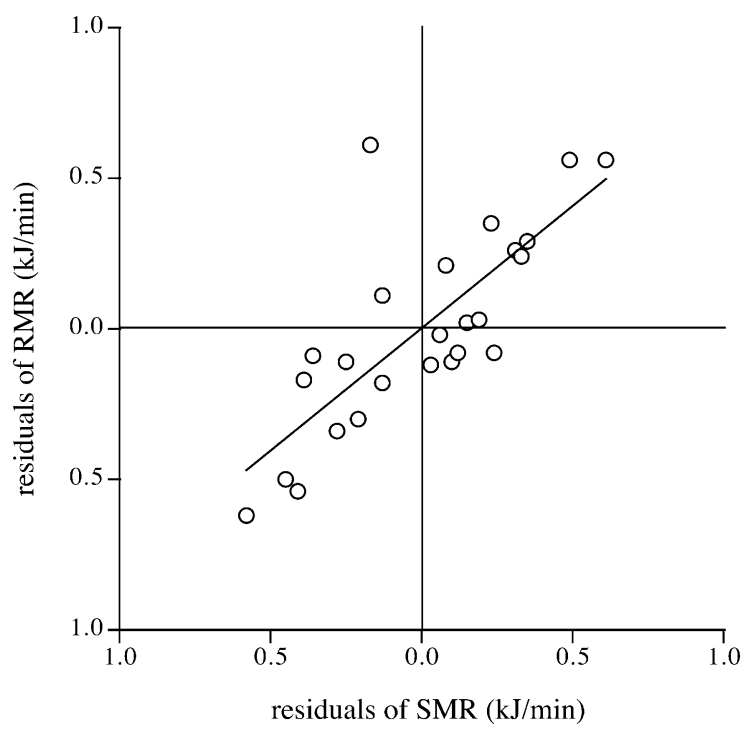

Fig. 1. Residuals of resting metabolic rate and FFM and FM versus residuals of sleeping metabolic rate and FFM and FM $\left(r^{2}=0.59, p<0.001\right)$.

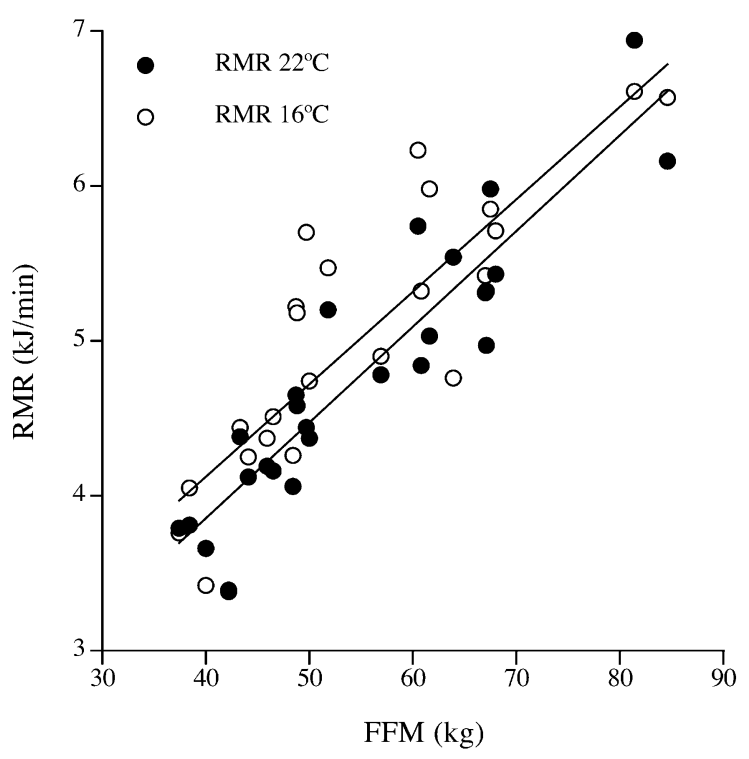

Fig. 2. Resting metabolic rate versus FFM at $22^{\circ} \mathrm{C}$ and $16^{\circ} \mathrm{C}$. $\mathrm{RMR}$ at $22^{\circ} \mathrm{C}(\mathrm{kJ} / \mathrm{min})=0.062 \mathrm{FFM}(\mathrm{kg})+1.353\left(r^{2}=0.85\right.$, $p<0.001)$. RMR at $16^{\circ} \mathrm{C}(\mathrm{kJ} / \mathrm{min})=0.060 \mathrm{FFM}(\mathrm{kg})+1.737$ $\left(r^{2}=0.71, p<0.001\right)$. The RMR was significantly higher at an ambient temperature of $16^{\circ} \mathrm{C}$ compared to $22^{\circ} \mathrm{C}(\Delta 5 \%, p<0.05$, ANCOVA) The slopes of the lines are comparable $(p>0.75$, ANCOVA).

\subsection{Temperature}

Intestinal temperature was not significantly different from rectal temperature in this study. Intestinal, rectal and $\mathrm{m}$. pectoralis temperatures were higher in women compared to men $(p<0.01, p<0.01, p<0.05$, respectively) (Table 2). Skin temperature measured at the back was slightly higher in women compared to men and hand temperature was slightly lower, but the difference was only significant during the last $2 \mathrm{~h}$ at $16^{\circ} \mathrm{C}$ $(p<0.05)$. No gender differences were found in the remaining skin temperatures (i.e. upper arm, liver, clothing, thigh, calf, foot). In spite of gender differences in skin temperature at specific sites, the average of proximal or distal skin temperatures was not significantly different and neither was average skin temperature.

No significant change of intestinal or rectal temperature was measured when ambient temperature decreased (Table 2). All skin temperatures decreased after the decrease in ambient temperature $(p<0.001)$. The temperature decrease was larger as the distance from the location to the core was larger. The increase in temperature gradient between intestinal and distal temperature was significantly larger than the increase in temperature gradient between intestinal and proximal temperature from $22^{\circ} \mathrm{C}$ to $16^{\circ} \mathrm{C}(p<0.001)$. Gradients 
Table 2

Skin, intestinal and rectal temperatures of men and women at $22^{\circ} \mathrm{C}$ and $16^{\circ} \mathrm{C}^{\mathrm{a}}$

\begin{tabular}{|c|c|c|c|c|}
\hline & \multicolumn{2}{|l|}{$22^{\circ} \mathrm{C}$} & \multicolumn{2}{|l|}{$16^{\circ} \mathrm{C}$} \\
\hline & M & $\mathrm{F}$ & M & $\mathrm{F}$ \\
\hline$T_{\text {intestine }}$ & $36.7 \pm 0.4$ & $37.3 \pm 0.6 * *$ & $36.7 \pm 0.5$ & $37.6 \pm 0.5^{* *}$ \\
\hline$T_{\text {rectum }}$ & $36.6 \pm 0.2$ & $37.0 \pm 0.3^{* *}$ & $36.6 \pm 0.3$ & $37.1 \pm 0.2^{* *}$ \\
\hline$T_{\text {pectoralis }} \mathrm{b}$ & $33.5 \pm 1.2$ & $34.3 \pm 0.5^{*}$ & $32.3 \pm 1.6$ & $33.4 \pm 0.8^{*}$ \\
\hline$T_{\text {back }}$ & $33.7 \pm 0.9$ & $34.2 \pm 0.7$ & $32.9 \pm 1.2$ & $33.7 \pm 0.8$ \\
\hline$T_{\text {hand }} \mathrm{b}$ & $31.6 \pm 2.4$ & $30.3 \pm 2.4$ & $27.5 \pm 3.6$ & $25.0 \pm 2.8$ \\
\hline$T_{\text {skin }_{\text {ave }}}$ b & $32.3 \pm 0.8$ & $32.4 \pm 0.4$ & $30.5 \pm 1.0$ & $30.8 \pm 0.5$ \\
\hline$T_{\text {proximal }} \mathrm{b}$ & $32.7 \pm 0.7$ & $32.9 \pm 0.4$ & $31.2 \pm 0.8$ & $31.6 \pm 0.5$ \\
\hline$T_{\text {distal }}{ }^{b}$ & $30.5 \pm 1.8$ & $29.6 \pm 1.5$ & $26.1 \pm 2.8$ & $24.9 \pm 1.7$ \\
\hline$T_{\text {skin-amb }}{ }^{\mathrm{b}}$ & $9.9 \pm 1.1$ & $9.8 \pm 0.7$ & $13.3 \pm 1.6$ & $12.3 \pm 0.8$ \\
\hline
\end{tabular}

${ }^{\text {a Note: }}{ }^{*} p<0.05, * * p<0.01$ males versus females.

${ }^{\mathrm{b}} p<0.0122^{\circ} \mathrm{C}$ versus $16^{\circ} \mathrm{C}$ (for the complete group as well as for males and females separately).

between proximal and distal temperature were significantly higher in women compared to men during the last $2 \mathrm{~h}$ at $16^{\circ} \mathrm{C}(p<0.05)$. Although temperature gradients between core and skin and between skin and environment were slightly smaller in women, no significant gender differences were found (Table 2). All calculated gradients increased significantly after the decrease in ambient temperature $(p<0.001)$ for both women and men separately as for the complete group. The increase in temperature gradient between skin and environment was significantly smaller in women during the first hour at $16^{\circ} \mathrm{C}(p<0.05)$. After including both gender and body fat percentage in multiple regression analysis, gender was still a significant explaining variable. Adjusted means after correcting for body fat percentage were $3.84^{\circ} \mathrm{C}$ and $4.60^{\circ} \mathrm{C}$ for women and men respectively.

\subsection{Relation of energy expenditure versus body temperature}

No relationships were found between the calculated residuals of energy expenditure and body temperatures. A negative relationship was found between absolute values of RMR and temperature gradients between core and skin $\left(r^{2}=0.37, p<0.001\right)$. In search for a relationship between heat production and heat loss, the RMR was compared with body surface area (BSA) and the gradient between skin and ambient temperature. Stepwise regression with RMR as dependent variable and as independent variables, BSA and the gradient between skin and ambient temperature, showed a significant contribution of the temperature gradient in addition to BSA at $22^{\circ} \mathrm{C}$ and the last hour at $16^{\circ} \mathrm{C}$ (respectively $\left.r^{2=} 0.84, r^{2=} 0.70, p<0.001\right)$. When ambient temperature decreased from $22^{\circ} \mathrm{C}$ to $16^{\circ} \mathrm{C}$, both the temperature gradient at the skin and the RMR increased. However, these changes were not related.

\section{Discussion}

Energy expenditure being explained for $85 \%$ by FFM is in concordance with previous literature (Bogardus et al., 1986; Ravussin and Bogardus, 1989). Earlier studies indicate individual RMR differences after correction for body composition (Ravussin and Bogardus, 1989). The relationship between residuals of SMR and RMR shows that subjects with a relatively high energy expenditure during the night have a relatively high energy expenditure during the day which is an individual characteristic. As no sign of shivering was reported after the decrease in ambient temperature, the increase in RMR indicates the existence of non-shivering thermogenesis during short-term exposure to a mild cold environment (Vybiral et al., 2000).

Higher intestinal and rectal temperatures in women compared to men are in agreement with the findings of Kim et al. (1998). Nine out of 13 female subjects were in post-ovulative state or using oral contraceptives on the measurement day, which could explain higher intestinal and rectal temperatures in women compared to men due to higher levels of (natural or synthetic) progestins. The slightly lower hand temperature at an ambient temperature of $22^{\circ} \mathrm{C}$ was not significant. This means that the results of Kim et al. (1998) who found a significantly lower hand temperature in women at room temperature were not reproduced in this study. The relative high skin temperatures measured at the back and $\mathrm{m}$. pectoralis site, in women compared to men could be caused by a relatively short distance to the core; however, a similar difference was not found for skin temperature near the liver.

Glickman-Weiss et al. (1999) found in men with low and high FM no significant difference in rectal temperatures caused by a significantly greater aerobic metabolic rate in the low fat group. In women, however the high fat group maintained a higher rectal 
temperature than the low fat group that did not have an accompanying higher RMR. This suggests that women have a lower capacity to increase the RMR. We found no significant gender difference in RMR increase. However, we did find a smaller increase in temperature gradient between skin and environment in women compared to men during the first hour at $16^{\circ} \mathrm{C}$, as gender was still a significant explaining variable after correcting for body fat percentage. This indicates a gender difference in vasoconstriction in response to a decrease in ambient temperature.

In summary, it appears that individual levels of energy expenditure during the night remained during the day. We found an increase in RMR without an increase in EMG activity in response to a decrease in ambient temperature, indicating non-shivering thermogenesis. Further we found gender differences in body temperature, and in temperature distribution in reaction to a decrease in ambient temperature indicating a difference in thermoregulation between genders.

\section{Acknowledgements}

We thank Anton van Steenhoven and Harry van Lenthe for constructive comments (University of Technology, Eindhoven, The Netherlands). Further we thank the Department of Movement Sciences of Maastricht University for availability of EMG equipment and Loek Wouters and Paul Schoffelen for technical support.

\section{References}

Bell, D.G., Tikuisis, P., Jacobs, I., 1992. Relative intensity of muscular contraction during shivering. J. Appl. Physiol. 72, 2336-2342.

Bogardus, C., Lillioja, S., Ravussin, E., Abbott, W., Zawadzki, J.K., Young, A., Knowler, W.C., Jacobowitz, R., Moll, P.P., 1986. Familial dependence of the resting metabolic rate. N Engl. J. Med. 315, 96-100.

Dauncey, M.J., 1981. Influence of mild cold on $24 \mathrm{~h}$ energy expenditure, resting metabolism and diet-induced thermogenesis. Br. J. Nutr. 45, 257-267.

Glickman-Weiss, E.L., Nelson, A.G., Hearon, C.M., Prisby, R., Caine, N., 1999. Thermal and metabolic responses of women with high fat versus low fat body composition during exposure to 5 and 27 degrees $\mathrm{C}$ for $120 \mathrm{~min}$. Aviat. Space. Environ. Med. 70, 284-288.

Huttunen, P., Lando, N.G., Meshtsheryakov, V.A., Lyutov, V.A., 2000. Effects of long-distance swimming in cold water on temperature, blood pressure and stress hormones in winter swimmers. J. Therm. Biol. 25, 171-174.

Kim, H., Richardson, C., Roberts, J., Gren, L., Lyon, J.L., 1998. Cold hands, warm heart [letter]. Lancet. 351, 1492.

O'Brien, C., Hoyt, R.W., Buller, M.J., Castellani, J.W., Young, A.J., 1998. Telemetry pill measurement of core temperature in humans during active heating and cooling. Med. Sci. Sports. Exerc. 30, 468-472.

Paolone, V.J., Paolone, A.M., 1995. Thermogenesis during rest and exercise in cold air. Can J. Physiol. Pharmacol. 73, 1149-1153.

Ramanathan, N.L., 1964. A new weighting system for mean surface temperature of the human body. J. Appl. Physiol. 19, 531-533.

Ravussin, E., Bogardus, C., 1989. Relationship of genetics, age, and physical fitness to daily energy expenditure and fuel utilization. Am. J. Clin. Nutr. 49, 968-975.

Rising, R., Keys, A., Ravussin, E., Bogardus, C., 1992. Concomitant interindividual variation in body temperature and metabolic rate. Am. J. Physiol. 263, E730-E734.

Schoffelen, P.F., Westerterp, K.R., Saris, W.H., Ten Hoor, F., 1997. A dual-respiration chamber system with automated calibration. J. Appl. Physiol. 83, 2064-2072.

Siri, W.E., 1956. The gross composition of the body. Adv Biol Med Physiol. 4, 239-280.

Smith, D.A., Dollman, J., Withers, R.T., Brinkman, M., Keeves, J.P., Clark, D.G., 1997. Relationship between maximum aerobic power and resting metabolic rate in young adult women. J. Appl. Physiol. 82, 156-163.

Tikuisis, P., Bell, D.G., Jacobs, I., 1991. Shivering onset, metabolic response, and convective heat transfer during cold air exposure. J. Appl. Physiol. 70, 1996-2002.

Valencia, M.E., McNeill, G., Brockway, J.M., Smith, J.S., 1992. The effect of environmental temperature and humidity on $24 \mathrm{~h}$ energy expenditure in men. Br. J. Nutr. 68, 319-327.

van Marken Lichtenbelt, W.D., Westerterp-Plantenga, M., van Hoydonck, P., 2000. In: Werner, J., Hexamer, M. (Eds.), Environmental Ergonomics IX. Shaker Verlag, Aachen, pp. $51-54$.

Vybiral, S., Lesna, I., Jansky, L., Zeman, V., 2000. Thermoregulation in winter swimmers and physiological significance of human catecholamine thermogenesis. Exp. Physiol. $85,321-326$.

Weir, J.B., 1990. New methods for calculating metabolic rate with special reference to protein metabolism. 1949 [classical article]. Nutrition. 6, 213-221. 